\title{
Pengembangan Model Permainan Dribbling Untuk Pembelajaran Teknik Dasar Sepakbola Di Smp It Al-Hikmah Parakansalak
}

\author{
Development Of Dribbling Game Models For Learning Basic Football \\ Techniques In Smp It Al-Hikmah Parakansalak
}

\author{
Rega Rivo Inzaghi \\ Program Studi PJKR, Universitas Muhammadiyah Sukabumi, Indonesia \\ Email: regarivo99@gmail.com
}

\begin{abstract}
Abstrak
Penelitian dan pengemabngan model permainan dribbling sepakbola ini bertujuan untuk mengetahui kelayakan permainan yang telah dikembangkan. Pengembangan permainan dribbling ini digunakan oleh siswa SMP dalam pembelajaran sepakbola di sekolah yang betujuan untuk membuat suasana belajar yang aktif dan menyenangkan bagi siswa. Penelitian ini adalah penelitian dan pengembangan (R\&D) yang mengacu pada model pengembangan Sugiyono yang terdiri dari 10 langkah, yaitu : (1) potensi dan masalah; (2) pengumpulan data; (3) desain prosuk; (4) validasi desain; (5) revisi desain; (6) uji coba produk; (7) revisi produk; (8) uji coba pemakaian; (9) revisi produk dan (10) produksi masal. Subjek dalam penelitian ini adalah siswa SMP IT Al-Hikmah Parakan Salak tahun 2019 yang berjumlah 50 orang. Teknik pengambilan sampel kdalam penelitian ini menggunakan teknik Snowball Sampling. Teknik analisis data yang digunakan yaitu analisis deskriptif kuantitatif dan analisis deskriptif kualitatif. Hasil penelitian dan pengembangan ini merupakan produk permainan dribbling untuk pembelajaran teknik dasar sepakbola yang diperuntukan bagi siswa sekolah menengah pertama. Model permaianan dribbling yang dikembangkan teridiri dari empat jenis permainan, yaitu : (1) Giring lari; (2) Pagaw; (3) O Dribb; (4) Essuka. Rata-rata persentase yang diperoleh dari ke empat jenis permainan tersebut sebesar $87 \%$ dengan kriteria sangat baik. Model permainan disusun dalam buku panduan berjudul "Pengembangan Permainan Dribbling untuk Teknik Dasar Sepakbola di SMP IT Al-Hikmah Parakan Salak".

Kata kunci : Pengembangan, Model Permainan, Dribbling Sepakbola, Sekolah Menengah Pertama.
\end{abstract}

\begin{abstract}
Research and development of this dribbling game model of football aims to find out the feasibility of the game that has been developed. The development of this dribbling game is used by junior high school students in learning football in schools aimiing to create an active and pleasant learning atmosphere for students.This research and development $(R \& D)$ refers to Sugiyono's development model which consists of 10 steps, including: (1) potential and problems; (2) data collection; (3) product design; (4) design validation; (5) design revisions; (6) product trials; (7) product revisions; (8) trial use; (9) product revisions and (10) mass production. The subjects in this study were 50 students of Junior High School of IT AlHikmah of Parakan Salak. The Snowball Sampling technique was used as the sampling technique in this study. Data analysis techniques used were quantitative descriptive and
\end{abstract}


qualitative descriptive analyses.The results of this research and development are dribbling game products for learning basic techniques of football intended for junior high school students. The dribbling game model developed consists of four types of games, including: (1) Running dribbles; (2) Pagaw; (3) O Dribb; (4) Essuka. The average percentage obtained from the four types of games is $87 \%$ with very good criteria. The game model is compiled in a guide book entitled "The Development of Dribbling Games for Basic Techniques of Football in Junior High School of IT Al-Hikmah of Parakan Salak".

Keywords: Development, Game Model, Football Dribbling, Junior High School.

\section{PENDAHULUAN}

Pendidikan memiliki peranan yang penting dalam kehidupan. Pendidikan merupakan suatu usaha agar manusia dapat mengembangkan potensi yang dimiliki dalam dirinya melalui proses pembelajaran. Proses pembelajaran bisa didapatkan salah satunya melalui pendidikan formal. Pendidikan formal merupakan pendidikan yang diselenggarakan di sekolah di bawah naungan lembaga pendidikan, yang termasuk dalam pendidikan formal yaitu Sekolah Dasar (SD), Sekolah Menengah Pertama (SMP) dan Sekolah Menengah Atas (SMA) sebagaimana tercantum di dalam UU NO 20 Tahun 2003 yang menyebutkan bahwa "Pendidikan formal adalah jalur pendidikan yang terstruktur dan berjenjang yang terdiri atas pendidikan dasar, pendidikan menengah, dan pendidikan tinggi”. Sekolah menjadi tempat untuk berbagi ilmu antara guru dan siswanya. Pendidikan memiliki peranan yang sangat penting karena pendidikan menjamin kelangsungan hidup bangsa.

Pendidikan Jasmani menurut Junaedi (2015: 836) "Pendidikan jasmani, olahraga, dan kesehatan merupakan bagian dari pendidikan nasional yang harus melibatkan unsur-unsur penting berupa fikiran dan tubuh. Dimana semua aspek tersebut sangat berkaitan dalam kehidupan sehari-hari untuk menjadikan masingmasing individu agar menjadi baik". Pendidikan jasmani memiliki peranan yang penting, karena dengan terlibatnya siswa dalam proses belajar mengajar dapat memberikan dampak baik bagi siswa. Pendidikan jasmani di sekolah memilliki beberapa materi pembelajaran, seperti bolavoli, senam, renang, atletik, sepakbola dan masih banyak materi pembelajaran lainnya.

Pembelajaran sepakbola di sekolah seringkali menjadi materi yang paling diminati oleh para siswa, namun berbeda dengan para siswi yang terlihat kurang begitu antusias dalam pembelajaran sepakbola. Berdasarkan hasil wawancara yag dilakukan bersama dengan guru PJOK di sekolah, bahwa masih terdapat beberapa kelemahan yang terjadi pada saat pembelajaran sepakbola yaitu, masih kurangnya modifikasi permainan yang diberikan pada saat pembelajaran sepakbola khususnya pada materi menggiring (dribbling) bola yang belum dikemas secara menarik dalam bentuk modifikasi permainan sehingga antusias atau minat dari siswa siswi masih kurang dan siswa siswi mudah merasa bosan.

Berdasarkan permasalahan yang ditemukan di lapangan perlu adanya suatu solusi untuk meningkatkan antusias dari siswa siswi dalam mengikuti pembalajaran sepakbola di sekolah. Oleh karena hal tersebut penulis mencoba menyusun penelitian berdasarkan permasalahan yang telah di paparkan di atas dengan membuat produk permainan yang dapat digunakan dalam pembelajaran sepakbola pada materi menggiring (dribbling.

\section{SEPAKBOLA}

Sepakbola merupakan salah satu olahraga beregu yang dimainkan oleh dua kesebelasan untuk mencetak gol sebanyak-banyaknya ke gawang lawan. Menurut Rianto 
(2019: 294) "sepakbola dalam permainannya dimainkan dengan dua tim yang masing-masing dalam satu tim beranggotakan sebelas pemain dan lebih dikenal juga dengan sebutan dua kesebelasan yang saling berusaha mencetak gol ke gawang lawan". semakin berkembangnya sepakbola saat ini tidak hanya sebuah pertandingan melainkan juga sebuah pertunjukan yang dapat di jadikan sarana hiburan bagi masyarakat.

Sepakbola menjadi media bagi masyarakat untuk berinteraksi dan bierolahraga secara beregu, karena di dalam sebuah permainan sepakbola membutuhkan jumlah orang yang banyak sehingga memunculkan komunikasi dan interkasi baik antar pemain atau pun dengan lawan main, seperti yang diungkapkan oleh Hidayat (2017: 13) yang menyatakan "satu tim membutuhkan 11 pemain, maka dalam dua tim yang bertanding tentu membutuhkan 22 orang, hal tersebut membantu terciptanya proses sosial pada pemain di lapangan".

\section{MANFAAT BERMAIN SEPAKBOLA}

Permainan sepakbola menjadi permainan yang menyenangkan yang dapat dijadikan sebagai olahraga rekreasi atau hiburan bagi masyarakat selain itu juga bermain sepakbola dapat meningkatkan kondisi tubuh. sepakbola memiliki beberapa manfaat bagi tubuh, dapat mencegah pola hidup tidak sehat karena bermain sepakbola diperlukan kondisi tubuh yang prima. Manfaat bermain sepakbola memiliki banyak manfaat yang baik bagi tubuh seperti yang dikutip dari Taufik (2019) "Permainan Sepakbola memiliki manfaat yang cukup besar dalam pembentukan individu yang sportif dalam perkembangan jasmani maupun rohaninya". Adapun beberapa diantaranya manfaat bermain sepakbola yang dikutip dari Hidayat (2017: 13), yaitu: (1) meningkatkan kekuatan otot tangan dan otot kaki; (2) meningkatkan kordinasi mata, tangan dan kaki; (3) mencegah pola hidup tidak sehat; (4) menumbuhkan semangat nasionalisme; (5) dan dapat dijadikan sebagai media bisnis. Banyak manfaat yang bisa didapatkan melalui bermain sepakbola baik untuk kesehatan yang beberapa diantaranya yaitu meningkatkan kardiovaskular, melatih konsentrasi, melatih sensitivitas, meningkatkan kekuatan otot kaki dan tangan.

\section{TEKNIK DASAR MENGGIRING (DRIBBLING)}

Sepakbola memiliki beberapa Teknik dasar diantaranya dribbling, pasising, stop ball, heading, kicking dan masih banyak teknik dasar lainnya. Teknik dasar dalam sepakbola sangatlah penting seperti yang dikemukan oleh Aji (2016:1) " teknik dasar adalah gserakan dasar yang harus dikuasai oleh seorang pemain sepak bola" Teknik dasar dribbling dalam permainan sepakbola merupakan salah satu teknik dasar yang sangat penting seperti yang dikemukakan oleh hidayat "menggiring bola merupakan kegiatan mengontrol pergerakan bola dengan menggunakan kaki". Teknik sepakbola merupakan basic pada permainan sepakbola sehingga para pemain dituntut untuk menguasai teknik dasar dengan baik.

Teknik dasar menggiring (dribbling) dalam permainan sepakbola, merupakan salah satu teknik dasar yang amat begitu penting dalam permainan sepakbola. Menurut Hidayat (2017: 30) "menggiring bola merupakan kegiatan mengontrol pergerakan bola dengan menggunakan kaki”. Dengan teknik menggiring bola yang baik, maka seorang pemain cenderung akan mampu menguasai bola dan akan mampu untuk melewati lawan dengan baik, seperti yang didefinisikan oleh Hasanah (2009: 47) "dribbling sepakbola sebagai cara menguasai bola dengan kaki pada saat kamu bergerak atau bermain di lapangan”. Kedua pendapat tersebut senada dengan yang diungkapkan oleh Aji (2016: 8) yaitu, "menggiring bola adalah gerakan membawa bola dengan menggunakan kaki untuk menuju daerah pertahanan lawan dan menerobos pemain lawan". Penguasaan bola menjadi sangat penting karena para pemain harus menggiring bola ke daerah pertahan lawan. Teknik menggiring bola dapat dilakukan dengan punggung kaki bagian luar, punggung kaki bagian dalam dan dapat dikombinasikan kaki bagian luar dan bagian dalam 
Teknik dasar dribbling merupakan suatu teknik dasar atau keterampilan untuk menggiring dan mengontrol bola baik menggunakan kaki bagian luar, kaki bagian dalam ataupun dengan menggunakan punggung kaki dengan cara berlari yang bertujuan untuk menerobos lawan.

\section{KARAKTERISTIK SMP}

Sekolah Menengah Pertama berada pada masa peralihan masa anak-anak menuju remaja yang mana siswa SMP ini berkisar antara umur 12-16 tahun. Pada usia tersebut remaja memiliki kestabilaan emosi yang masih labil, membutuhkan bimbingan dan perhatian yang lebih dari orang tua dan guru agar siswa siswi SMP tidak salah dalam bergaul, sudah memiliki kecenderungan minat yang lebih jelas, dan sudah nampak perbedaan kemampuan yang dimiliki oleh laki-laki dan perempuan. Menurut Desmita (2017: 36) beberapa karakteristik siswa usia Sekolah Menengah Pertama (SMP) diantaranya sebagai berikut: (1) Terjadi ketidakseimbangan proporsi tinggi dan berat badan; (2) Mulai timbulnya ciri-ciri seks sekunder; (3) Reaksi dan ekspresi emosi masih labil

\section{MODEL PERMAINAN MENGGIRING (DRIBBLING)}

Peneliti mengembangkan produk permainan dengan menggunakan teknik dasar menggiring dalam sepakbola. Permainan yang dikembangkan oleh peneliti dengan menggunakan alat dan bahan yang terdapat disekitar sekolah beberapa diantaranya seperti bola sepak, cones, dan lapangan. Permainan yang dikembangkan ada empat jenis permainan menggiring yang dibuat semenarik mungkin untuk siswa SMP. Empat jenis permainan yang dikembangkan yaitu : (1) Permainan Giring Lari; (2) Permainan Pagaw (Empat Gawang), (3) Permainan O Dribb dan; (4) Permainan Essuka (Estafet Sumpit Kayu). Model permainan yang dikembangkan menggunakan bahasa yang mudah di pahami, memuat aturan permainan, alat dan bahan yang aman untuk digunakan, serta penjelasan mengenai tata cara pelaksanaan dari permainan tersebut sehingga mudah utuk di pahami oleh pembaca.

\section{METODE PENELITIAN}

Metode yang digunakan dalam penelitian ini yaitu metode penelitian dan pengembangan. Menurut Sugiyono (2018: 297) "Metode penelitian dan pengembangan Research and Development (R\&D) merupakan suatu metode penelitian yang digunakan untuk menghasilkan produk tertentu, dan menguji keefektifan dari produk tersebut". Produk yang akan peneliti kembangkan dalam penelitian ini yaitu pengembangan untuk menghasilkan produk permainan yang dapat digunakan didalam pembelajaran sepakbola disekolah dengan materi dribbling. Dalam penelitian dan pengembangan ini terdapat langkah-langkah penelitian dan pengembangan yang dilakukan sebagai berikut : (1) Potensi dan masalah; (2) Pengumpulan informasi; (3) Desain Produk; (4) Vaidasi desain; (5) Revisi Desain; (6) Uji coba produk; (7) Revisi produk; (8) Uji coba pemakaian; (9) Revisi produk dan; (10) Produksi masal. Hasil produksi masal yang dihasilkan dalam penelitian dan pengembangan ini merupakan buku panduan permainan dribbling yang dapat di implementasikan oleh praktisi di dalam pembelajaran sepakbola di sekolah.

\section{- Potensi dan Masalah}

Potensi dan masalah yang akan diteliti dalam penelitian ini mengenai permasalahan yang terjadi dilapangan yaitu kurangnya modifikasi permainan yang dilakukan oleh guru di dalam pembelajaran penjas khususnya pada materi dribbling sepakbola, selain itu sarana dan prasarana pembelajaran yang kurang memadai, dan minat peserta didik yang masih kurang terhadap pembelajaran sepakbola. Penelitian dan pengembangan produk permainan yang dilakukan oleh peneliti dengan 
menggunakan teknik dasar dribbling sepakbola. Melalui produk yang dikembangkan dengan kegiatan bermain diharapkan dapat mengatasi permasalahan yang terjadi di lapangan.

\section{- Pengumpulan Informasi}

Setelah menemukan potensi dan masalah yang terjadi di lapangan, barulah peneliti mengumpulkan infomasi yang dapat digunakan sebagai bahan perencanaan produk permainan dalam pembelajaran sepakbola yang akan dikembangkan oleh peneliti. Dalam tahap pengumpulan informasi ini, peneliti mengumpulkan informasi sebagai bahan perencanaan untuk membuat konsep permainan yang akan dibuat oleh peneliti dan disesuaikan dengan karakteristik siwa Sekolah Menengah Pertama (SMP).

\section{- Desain Produk}

Desain produk dilakukan setelah peneliti mengumpulkan informasi yang sesuai dengan karakteristik dan permasalahan yang terjadi di lapangan. Desain produk permainan yang akan dikembangkan oleh peneliti menggunakan teknik dasar menggiring (dribbling) yang dibuat dengan gambar dan penjelasannya secara rinci. Produk permainan yang dikembangkan oleh peneliti sebanyak empat buah permainan dengan konsep permainan beregu dan individu.

\section{- Validasi dan Revisi Produk}

Validasi Desain dilakukan apabila peneliti sudah membuat desain produk permainan yang akan dikembangkan secara rinci dengan kejelasan gambar, peraturan, tata cara bermain, alat dan bahan serta kelengkapan lainnya. Validasi produk dalam penelitian ini diajukan kepada tiga orang validator yaitu, ahli bahasa, ahli sepakbola dan ahli permainan. Validasi desain ini akan diajukan kepada ahli bahasa. ahli sepakbola dan ahli permainan.

Revisi desain bertujuan untuk mengetahui kelemahan-kelemahan dan kekurangan yang terdapat di dalam rancangan produk yang dikembangkan oleh peneliti. Kelemahan tersebut selanjutnya akan dikurangi dengan melakukan perbaikan desain sesuai saran dan masukan yang telah diberikan oleh para ahli sebagai validator terhadap rancangan produk permainan untuk pembelajaran teknik dasar dribbling sepakbola di sekolah.

\section{- Uji Coba Produk dan Revisi Produk}

Uji coba produk dilakukan setelah peneliti memperbaiki desain rancangan pengembangan produk permainan yang dikembangkan sesuai dengan saran dan masukan yang diberikan oleh ahli. Uji coba produk pada tahap ini bertujuan untuk mengetahui dan menilai keefektifan dari produk permainan yang dikembangkan menggunakan skala kecil dengan jumlah sampel yang tidak terlalu besar atau banyak, peneliti menggunakan sampel sebanyak satu kelas pada tahap uji coba produk tersebut.

Setelah melakukan uji coba produk yang di dampingi oleh praktisi, kemudian peneliti melakukan revisi produk untuk memperbaiki dan meminimalisir kelemahan atau kekurangan yang terdapat di dalam produk permainan yang dikembangkan. Revisi produk yang dilakukan berdasarkan informasi dan penilaian yang telah dilakukan oleh praktisi pada tahap uji coba produk menggunakan skala kecil.

\section{- Uji Coba Pemakaian dan Revisi Produk}

Setelah dilakukan revisi produk dengan mengurangi kelemahan-kelemahan yang terdapat di dalam produk tersebut, selanjutnya akan dilakukan uji coba 
pemakaian dengan menggunakan skala yang lebih besar, hal ini di maksudkan untuk mengetahui dan menilai keefektifan dari produk yang dikembangkan tersebut. Pada tahap uji coba pemakaian skala besar ini peneliti menggunakan subjek penelitian sebanyak dua kelas.

Revisi produk dilakukan apabila masih terdapat kelemahan dan kekurangan di dalam produk yang dikembangkan. Revisi yang dilakukan berdasarkan saran masukan yang dilakukan oleh praktisi pada tahap uji coba pemakaian, hal ini dilakukan untuk menyempurnakan produk permainan yang dikembangkan oleh peneliti sebelum di produksi masal.

\section{- Produksi Masal}

Produksi masal dilakukan apabila revisi produk terhadap permainan yang dikembangkan sudah di validasi dan dinyatakan valid oleh ahli/ praktisi sehingga produk tersebut layak digunakan oleh guru di dalam pembelajaran sebagai referensi dalam memberikan pembelajaran PJOK dengan materi dribbling sepakbola di sekolah.

\section{Instrumen Penelitian}

- Lembar Validasi Produk

Lembar validasi produk digunakan untuk mengumpulkan data tentang penilaian validator terhadap validitas pengembangan model permainan dribbling yang dikembangkan.

- Lembar Penilaian Ahli/ Praktisi

Lembar penilaian yang diajukan kepada ahli/ praktisi berisi pertanyaan merupakan pertanyaan umum mengenai kemudahan dalam menyampaikan permainan, kemudahan dalam meyiapkan sarana dan prasarana yang digunakan dalam permainan, keamanan dari permainan yang dikembangkan, keefektifan dalam menerapkan permainan yang dikembangkan di dalam pembelajaran.

- Pencatatan Lapangan

Pencatatan lapangan dibuat oleh peneliti guna mencatat perbaikan, saran dan masukan yang diberikan oleh ahli maupun praktisi, selain itu juga catatan lapangan ini digunakan peneliti untuk mencatat hal-hal yang berkaitan dengan pengembangan model permainan untuk teknik dasar dribbling sepakbola di sekolah.

\section{Teknik Pengumpulan Data}

Teknik yang digunakan untuk pengumpulan data kuantitatif dan kualitatif. Pengambilan data pengembangan model permainan dribbling untuk pembelajaran sepakbola di sekolah menengah pertama ini dengan menggunakan angket skala nilai dan dokumentasi.

- Pengumpulan jenis data yang digunakan adalah data kuantitatif dan kualitatif yaitu :

a. Jenis data kuantitatif: penilaian skala nilai validasi, penilaian skala nilai pada observasi pelaksanaan permainan, dan penilaian skala observasi keefektifan produk pengembangan permainan.

b. Jenis data kualitatif: mencatat masukan dan saran perbaikan pada produk permainan yang dikembangkan, catatan lapangan, dan hasil observasi uji coba produk dan uji coba pemakaian.

- Angket Skala Nilai

Angket skala nilai digunakan sebagai instrumen untuk menilai kelayakan produk permainan. Angket skala nilai ditujukan untuk memperoleh penilaian dan validasi dari para ahli terkait konsep model permainan yang dikembangkan secara isi materi, bahasa dan format penulisan. Angket yang digunakan di dalamnya memuat 
faktor dan indikator penilaian kelayakan produk. Faktor yang digunakan dalam angket ini mengenai kualitas dari model permainan yang dikembangkan.

- Dokumentasi

Dokumentasi dilakukan dengan mengumpulkan foto dan video dari kegiatan validasi kepada ahli dan praktisi, kegiatan uji coba produk dan uji coba pemakaian hal ini bertujuan untuk penguatan informasi dan kevalidan data dari kegiatan penelitian dan pengembangan yang dilakukan.

\section{Teknik Analisis Data}

Teknik analisis data yang digunakan dengan teknik analisis data deskriptif persentase kuantitatif yang dilakukan pada: (a) hasil penilaian validasi dengan skala nilai ahli terhadap draf produk permainan sebelum uji coba, (b) data penilaian hasil observasi para observer terhadap pengembangan produk permainan, (c) data hasil observasi terhadap keefektifan pengembangan produk permainan untuk pembelajaran teknik dasar dribbling sepakbola di sekolah.

Hasil validasi yang telah diajukan kepada validator kemudian peneliti melakukan analisis data dengan menggunakan metode deskriptif kuantitatif. Berikut tabel kriteria penilaian yang digunakan dalam penelitian dan pengembangan ini :

Tabel 1 Kriteria Hasil Validasi Ahli/ Praktisi

\begin{tabular}{|c|c|}
\hline Nilai Skala & Penilaian \\
\hline 4 & Sangat Baik (SB) \\
\hline 3 & Baik (B) \\
\hline 2 & Cukup Baik(CB) \\
\hline 1 & Kurang Baik (KB) \\
\hline
\end{tabular}

Model permainan untuk pembelajaran teknik dasar dribbling sepakbola yang telah disusun dianggap layak untuk dilakukan uji coba produk dengan menggunakan skala kecil maupun skala besar apabila secara kuantitatif dihitung dengan menggunakan rumus sebagai berikut :

$$
p=\frac{f}{N} 100 \%
$$

\section{Keterangan :}

$\mathrm{f} \quad$ : Frekuensi yang sedang dicari persentasenya.

$\mathrm{N} \quad$ : Number of Case (jumlahfrekuensi/banyaknya individu).

$\mathrm{p} \quad$ : Angka persentase

Sumber : (Sudijono, 2017: 43)

Skor yang diperoleh kemudian dikonversikan menjadi nilai kualitatif sesuai dengan kriteria penilaian yang digunakan yaitu :

Tabel 3. 1 Kriteria Penilaian Skor Hasil Validasi Ahli/ Praktisi 


\begin{tabular}{|lc|c|}
\hline 4$)$ & Sangat Baik & $100 \%-76 \%$ \\
\hline 3$)$ & Cukup Baik & $51 \%-75 \%$ \\
\hline 2$)$ & Baik & $26 \%-50 \%$ \\
\hline 1$)$ & Kurang Baik & $0 \%-25 \%$ \\
\hline
\end{tabular}

Berdasarkan tabel kriteria penilaian tersebut dapat dijabarkan sebagai berikut, untuk kategori sangat baik berada pada rentang 76\%-100\%, sedangkan kategori baik berada pada rentang 51\%-75\%, untuk kategori baik dengan skor 26\%-50\%, dan kategori kurang baik dengan skor 0\%-25\%. Pengembangan model permainan yang dilakukan pada pembelajaran teknik dasar dribbling sepakbola di SMP IT Al-Hikmah Parakan Salak dinyatakan valid dan layak untuk dilakukan uji coba apabila skor yang diperoleh dari setiap jenis permainan mencapai minimal skor lebih dari $25 \%$.

\section{HASIL DAN PEMBAHASAN}

\section{Data Validasi Ahli}

Validasi Desain dilakukan untuk memvalidasikan konsep awal dari pengembangan model permainan dribbling untuk pembelajaran teknik dasar sepakbola di SMP IT AlHikmah Parakan Salak kepada ahli yang sesuai dengan bidang keahliannya. Kegiatan validasi konsep permainan ini perlu dilakukan sebelum peneliti melakukan uji coba produk dengan menggunakan skala kecil. Dalam kegiatan validasi desain ini peneliti melibatkan dua orang pakar ahli validasi (expert judgment) yaitu ahli sepakbola dan ahli permainan.

Hasil pengisian lembar evaluasi yang dilakukan oleh ahli sepakbola dan ahli permainan diperoleh hasil dengan rata-rata penilaian sebesar 76,5\% yang masuk pada rentang kategori "Sangat Baik", sehingga dapat disimpulkan bahwa pengembangan permainan dribbling sepakbola di SMP ini layak digunakan pada tahap uji coba pemakaian menggunakan skala kecil.

\section{Data Uji Coba Produk}

Uji coba produk dengan menggunakan skala kecil dilakukan setelah draf model permainan dribbling untuk pembelajaran teknik dasar sepakbola ini telah dinyatakan valid dan layak digunakan pada tahap selanjutnya yaitu uji coba pemakaian dengan skala kecil. Pada hari Kamis tanggal 21 November 2019 dilaksanakan uji coba produk permainan dribbling tersebut dengan menggunakan skala kecil oleh peneliti yang bertempat di SMP IT Al-Hikmah Parakansalak dengan jumlah siswa sebanyak 25 orang dari kelas 8B, dalam pelaksanaanya peneliti di dampingi oleh guru PJOK SMP IT Al-Hikmah Parakansalak.

Tujuan dilakukannya uji coba pemakaian dengan mengggunakan skala kecil ini guna mengetahui kelemahan dan kekurangan apa saja yang terdapat di dalam produk serta untuk menilai efektifitas dari permainan yang telah dikembangkan oleh peneliti. Dari kegiatan uji coba pemakaian ini peneliti memperoleh data yang dihimpun menggunakan kuisioner yang ditujukan untuk guru PJOK SMP IT Al-Hikmah Parakansalak sebagai praktisi untuk menilai kualitas produk permainan dribbling untuk pembelajaran teknik dasar sepakbola yang dilakukan dengan menggunakan kelompok kecil. Penilaian yang dilakukan oleh guru PJOK selaku praktisi dapat dilihat pada gambar grafik sebagai berikut : 


\section{Gambar 1. Grafik Rekapitulasi persentase Pengamatan Praktisi \\ Uji Coba Pemakaian Skala Kecil}

Berdasarkan pada gambar diatas menunjukan data dari empat jenis permainan yang dikembangkan diperoleh hasil skor rata-rata persentase sebesar $71,75 \%$ yang berada pada kategori "Cukup Baik". Dari hasil yang diperoleh tersebut maka model permainan dribbling ini layak untuk dilanjutkan pada tahap selanjutnya setelah melakukan beberapa revisi sesuai saran dan komentar yang diberikan oleh praktisi hingga dinyatakan layak untuik dilanjutkan pada tahap uji coba produk dengan menggunakan skala yang lebih besar.

\section{Data Uji Coba Pemakaian} pemakaian Uji coba dengan skala besar ini

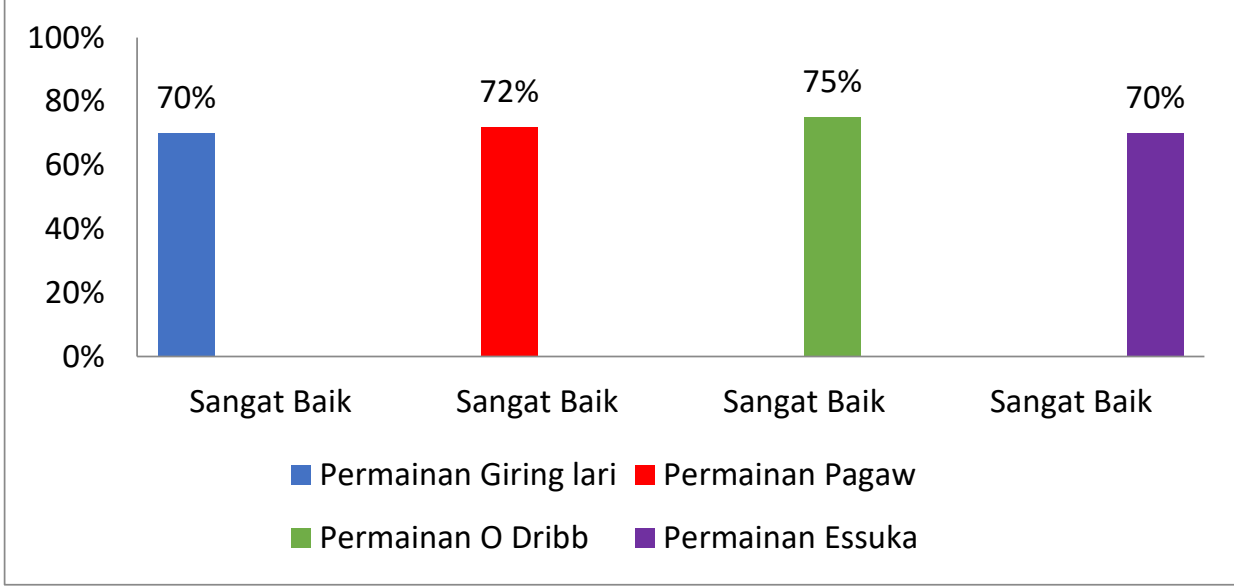
dilaksanakan

pada hari Kamis 11 Desember 2019 yang bertempat di SMP IT Al-Hikmah Parakansalak sebanyak dua kelas yaitu kela 8A dan kelas 8B dengan jumlah siswa 50 orang, serta didampingi oleh Guru PJOK/ praktisi. Data uji coba pemakaian ini dihimpun dengan menggunakan kuisioner yang diisi oleh praktisi. Berikut merupakan data hasil rekapitulasi penilaian yang diberikan oleh praktisi pada uji coba pemakaian : 


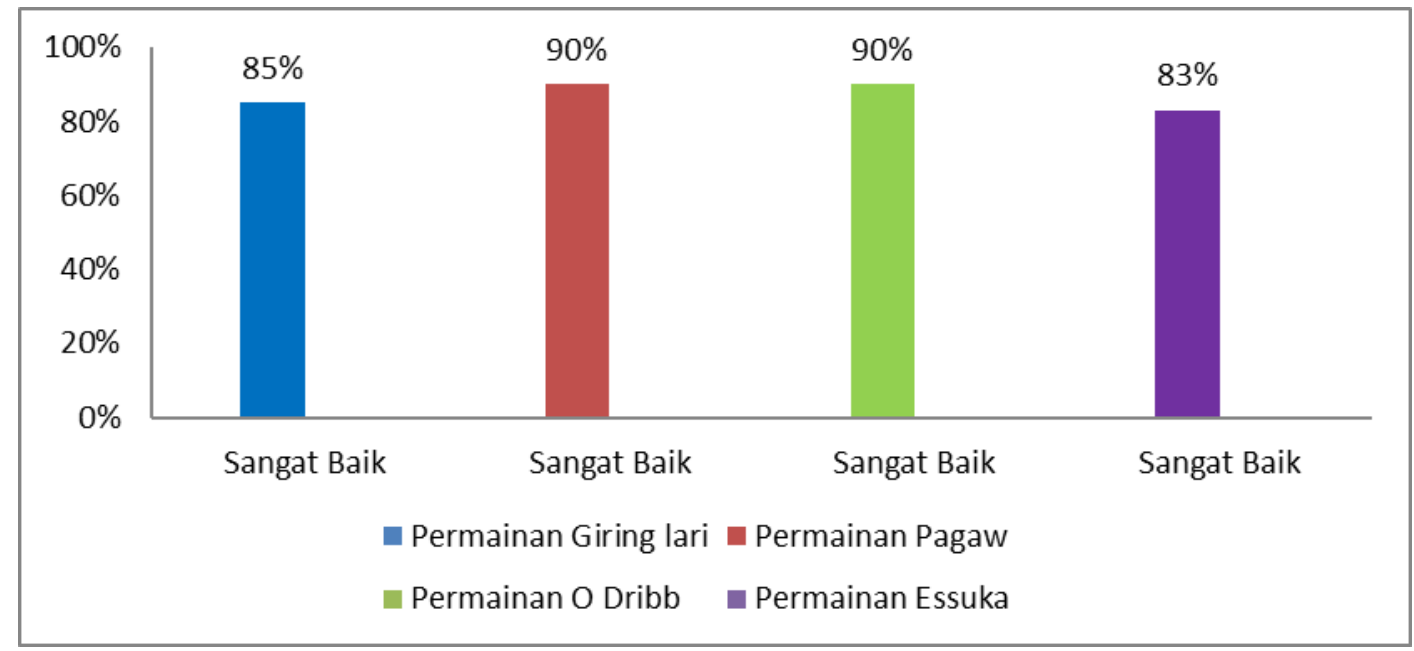

Gambar 2. Grafik Rekapitulasi Penilaian oleh Praktisi pada Uji Coba Pemakaian dengan

\section{Skala Besar}

Pada gambar grafik diatas, diperoleh rata-rata persentase sebesar $87 \%$ yang termasuk dalam kategori "Sangat Baik" berdasarkan kriteria yang telah ditentukan, sehingga permainan dribbling untuk pembelajaran teknik dasar sepakbola tersebut layak digunakan untuk siswa Sekolah Menengah Pertama, khususnya SMP IT Al-Hikmah Parakansalak.

Produk akhir yang dihasilkan dari penelitian dan pengembangan ini merupakan sebuah produk permainan dribbling untuk pembelajaran Teknik dasar sepakbola yang kemudian dimuat di dalam sebuah buku panduan sebagai hasil produk akhir penelitian dan pengembangan yang telah dilakukan oleh peneliti .

\section{KESIMPULAN}

Berdasarkan analisis dan pembahasan yang telah dilakukan oleh peneliti mengenai penelitian dan pengembangan permainan dribbling untuk pembelajaran Teknik dasar sepakbola pada siswa kelas VIII di SMP IT Al-Hikmah Parakan Salak memberikan respon positif baik dari siswa dan guru mata pelajaran PJOK di sekolah.

Hasil akhir dari kegiatan penelitian ini adalah sebuah produk permainan dribbling sepakbola yang diperuntukan khusus untuk siswa Sekolah Menengah Perama pada pembelajaran sepakbola. Berdasarkan data pada saat melakukan uji coba produk dan uji coba pemakaian dapat disimpulkan sebagai berikut :

1. Produk pengembangan permainan dribbling Giring Lari dinyatakan layak untuk digunakan di dalam pemebelajaran sepakbola dengan rata-rata persentase $85 \%$ dengan kategori sangat baik.

2. Produk pengembangan permainan dribbling Pagaw dinyatakan layak untuk digunakan di dalam permabelajaran sepakbola dengan rata-rata persentase $90 \%$ dengan kategori sangat baik.

3. Produk pengembangan permainan dribbling $\mathrm{O}$ Dribb dinyatakan layak untuk digunakan di dalam permabelajaran sepakbola dengan rata-rata persentase $90 \%$ dengan kategori sangat baik.

4. Produk pengembangan permainan dribbling Essuka dinyatakan layak untuk digunakan di dalam permabelajaran sepakbola dengan rata-rata persentase $83 \%$ dengan kategori sangat baik.

Dari kelima jenis permainan dribbling yang dihasilkan diperoleh rata-rata persentase sebesar $87 \%$ dengan kriteria yang telah ditentukan berada pada kategori "Sangat Baik", 
sehingga dapat disimpulkan bahwa produk permainan dribbling untuk pembelajaran Teknik dasar sepakbola ini layak untuk digunakan di dalam pembelajaran karena mengandung aspek kognitf, afektif dan psikomotorik. Selain itu dalam permainan dribbling ini dapat menumbuhkan nilai-nilai kerjasama, nilai sportivitas, nilai kejujuran, dan membuat siswa lebih aktif bergerak dengan cara yang menyenangkan. Melalui permainan dribbling ini guru dapat memberikan materi pembelajran dribbling dengan cara yang berbeda yaitu dengan menggunakan permainan.

\section{DAFTAR PUSTAKA}

Aji, S. (2016). Buku Olahraga Paling Lengkap (Alwi (ed.); 1st ed.). Ilmu.

Desmita. (2017). Psikologi Perkembangan Peserta Didik (Ctk.7). PT Remaja Rosdakarya.

Hasanah, I. (2009). Sepak Bola. PT Indahjaya Adipratama.

Hidayat, W. (2017). Buku Pintar Sepak Bola (1st ed.). Anugrah.

Junaedi, A. (2015). Jurnal Pendidikan Olahraga dan Kesehatan Volume 03 Nomor 03 Tahun.

Jurnal Pendidikan Olahraga Dan Kesehatan, 3(3), 834-842.

http://ejournal.unesa.ac.id/index.php/jurnal-pendidikan-jasmani/issue/archive

Rianto, A. (2019). Pengaruh Latihan Small Sided Games 6 lawan 6 dan 7 lawan 7 Terhadap

Kelincahan dan Keterampilan Dribbling Pemain Sepakbola. Jurnal Mitra Pendidikan (JMP Online), 3(2), 293-304.

Sudijono, A. (2017). Pengantar Statistik Pendidikan (1st-18th ed.). PT Rajagrafindo persada. Sugiyono. (2018). Metode Penelitian Kuantitatif, Kualitatif, dan $R \& D$ (Ctk.3). Alfabeta Cv.

Taufik. (2019). Pengaruh Koordinasi Mata-Kaki Kelincahan dan Kecepatan dengan Kemampuan Menggiring Bola pada Permainan Sepakbola pada Siswa SMA Negeri 11 Makasar. Universitas Negeri Makasar. 